\title{
Due diligence as a conflict prevention tool in Democratic Republic of the Congo
}

\section{La diliigencia debida como herramienta de prevención del conflicto en la República Democrática del Congo}

\section{Ilari Aula}

PhD from the London School of Economics and Political Science. aulailari@gmail.com

How to cite this article: Aula, Ilari. "Due diligence as a conflict prevention tool in Democratic Republic of the Congo". Revista CIDOB d'Afers Internacionals, issue 125 (September 2020), pp. 61-85. DOI: doi.org/10.24241/rcai.2020.125.2.61/en

\begin{abstract}
This paper explores mandatory due diligence schemes in supply chains as conflict prevention tools in the eastern region of the Democratic Republic of Congo (DRC). Drawing on reports and fieldwork, it argues that their impact on violence in the region has been ambiguous. One reason for these mechanisms' shortcomings is that they address the role minerals play in this conflict from the perspective of "conflict resources" and "resource conflicts". Giving consideration to the "resource curse" would help address how the militarisation of competition between elites and weak state institutions make minerals factors of conflict. In practice, this would mean recognising that international measures against transnational money laundering and illicit capital flows are vital to tackling the link between minerals and conflict.
\end{abstract}

Keywords: armed conflicts, sanctions on raw materials, conflict minerals, due diligence, Democratic Republic of the Congo
Resumen: Este artículo explora los regímenes obligatorios de diligencia debida en las cadenas de suministro como herramienta de prevención del conflicto en la región oriental de la República Democrática del Congo (RDC). Basándose en informes y en un trabajo de campo, argumenta que su impacto sobre la violencia en la región ha sido ambiguo. Una de las razones que explican las limitaciones de estos regímenes es que abordan el papel que juegan los minerales en este conflicto desde la perspectiva de los «recursos de conflicto» y de los «conflictos de recursos». La perspectiva de la «maldición de los recursos» contribuiría a explicar cómo la militarización de la competición entre las élites y la fragilidad de las instituciones estatales perfilan los minerales como un factor de conflicto. En la práctica implicaría reconocer que las medidas internacionales contra el lavado transnacional de dinero y los flujos ilícitos de capital son vitales para hacer frente al vínculo entre minerales $y$ conflicto.

Palabras clave: armed conflicts, sanctions on raw materials, conflict minerals, due diligence, Democratic Republic of the Congo 
Since the end of the Cold War, international sanctions have evolved from comprehensive embargoes against state entities to targeted sanctions against individuals and groups, and to an instrument harnessed for diverse foreign policy purposes (Giumelli, 2011; Biersteker et al., 2016; Portela, 2010). As a distinct thread of this development, innovative import regimes against 'conflict resources' have emerged in the $2000 \mathrm{~s}^{1}$. Western civil society organisations have suggested that trade in some commodities contributes to armed conflicts and human rights violations abroad, and urged governments and companies to break this connection. Subsequently, over the years corporate supply chain programmes, soft law regulation, and multi-stakeholder initiatives have sprouted. Probably the best-known initiative is the Kimberley Process Certification Scheme which seeks to prevent trade in diamonds used to finance a civil war against legitimate govern-

\section{Mandatory supply chain due diligence re- quirements put companies in the driver's seat when ensuring that corporate activities to acquire raw materials abroad do not benefit perpetrators of armed violence and human rights violations.}

ments. A related one, on which this article focuses, is the conflict mineral approach centred on the DRC and its neighbouring states (UN, 2011; OECD, 2018; Bieri, 2010).

Mandatory supply chain due diligence requirements put companies in the driver's seat when ensuring that corporate activities to acquire raw materials abroad do not benefit perpetrators of armed violence and human rights violations. By requiring transparency in companies' supply chains, governments do not impose a straightforward ban on imports of questionable origins, but rely on the logic that individual consumers, large retailers and public agencies avoid products not meeting certain social and environmental standards once they are able to distinguish them (Vlaskamp, 2019). The schemes are related to commodity sanctions, but they also constitute a form of global governance, through which policy-makers, corporations and civil society associations orchestrate tasks that no actor could effectively manage alone. In a way, they move beyond sanctions by merging an inter-state import/export control regime with a voluntary industry-led certification system (Abbott and Snidal, 2009; Haufler, 2009).

1. As per Global Witness, an NGO, conflict resources are 'natural resources whose systematic exploitation and trade in a context of conflict contribute to, benefit from or result in the commission of serious violations of human rights, violations of international humanitarian law or violations amounting to crimes under international law' (Global Witness, 2006). 
This article engages with the functioning of such schemes as a conflict prevention and resolution tool in eastern DRC. While in no way providing a full account of the conflict dynamics, it applies a conceptual triad framework to help explain some challenges the due diligence schemes in the area are currently facing. The first part briefly discusses existing literature on the complicated relationship between natural resources and armed conflicts, and introduces the triad framework. The second part draws on the latest reports and fieldwork to argue that the impact of the due diligence schemes on violence in eastern DRC has so far been ambiguous ${ }^{2}$. The third part applies the triad framework to suggest that the shortcomings of the schemes partly result from them drawing on the 'resource conflict' and 'conflict resource' perspectives. Giving more space to the 'resource curse' perspective would help recognise the way the weakness of state institutions and the militarised competition between elite shape minerals into one of the many drivers in the conflict. Put into practice, such a change of lens would include building stronger connections between the conflict mineral approach as it stands now, and international work against money laundering and illicit capital flows.

\section{A triad conceptual framework}

This article builds on three strands of literature. First, research on the resource curse broadly studies whether a plethora of miseries, such as slow economic growth, bad governance, and corruption, and armed conflicts, is linked with a state or an area having or making use of abundant natural resources. While the connection may change over time, varies with geographical distribution, and the hypothesised causal mechanisms remain debated, quantitative studies broadly indicate that there is a basis for treating abundant natural resources, especially oil, as conducive to some of the pathologies (Haber and Menaldo, 2011; Ross, 2012; Sachs and Warner, 1995).

2. The fieldwork was conducted as part of the author's PhD research in 2017 (Aula 2019). Most of the approximately 30 semi-structured interviews took place in Bukavu and Goma, and some in Paris, London, and Brussels. The interviewees included policymakers, corporate representatives and civil society representatives. The interviewees agreed to their names being published. They were reached through snowballing sampling, a major starting point being the OECD Forum on Responsible Mineral Supply Chains (Paris, May 2017). 
Second, a specific thread of the research zooms in on the connection between natural resources and armed conflicts. Much work has been methodologically inspired by economic theories of conflicts. Often, they are articulated under the so-called greed and grievance debate on whether conflicts can usually be explained by parties to conflict wanting to improve their financial position, or by other causes, such as ethnic tensions or social inequality (Collier and Hoeffler, 2004; Keen, 2012). Researchers have identified, tested and categorised several causal mechanisms between natural resources and armed conflicts (Humphreys, 2005; Ross, 2004). The methodologies have grown more diverse and developed from cross-country conflict models towards micro-level analyses (Nillesen and Bulte, 2014; Gilberthorpe and Papyrakis, 2015).

Third, whether commodity sanctions, such as those imposed on diamonds, oil and timber stemming from specific areas, serve conflict prevention and

Le Billon's political ecology approach emphasises natural resources as socially mediated rather than as deterministic factors in a given conflict. The relation between natural resources and conflict is often articulated only in one or two of the three possible ways. other aims has been scrutinised over the years. While, for instance, Biersteker et al. suggest that commodity sanctions can be effective when complementing other sanctions, such as arms embargoes, other research suggests that their benefits remain ambiguous (Biersteker et al., 2013, 40; Carisch et al., 2017; Drezner 2011; Le Billon, 2008; Weiss, 1999). Similarly, the track record of the due diligence schemes is mixed. The Kimberley Process has been praised for making diamond supply chains more transparent, but criticism persists regarding its alleged shortcomings in isolating supply chains from forced labour, armed rebels and violent state actors (Global Witness, 2011; Acosta, 2013; Le Billon, 2006). As cases are few, making strong generalisations regarding the role of due diligence schemes in alleviating conflicts remains difficult.

This article harnesses a conceptual triad framework introduced by Philippe Le Billon to create some order among the many causal mechanisms between natural resources and armed conflicts hypothesised in the vast literature, and to help understand when, how, and for what purposes the due diligence schemes can be harnessed. Le Billon's political ecology approach emphasises natural resources as socially mediated rather than as deterministic factors in a given conflict. The relation between natural resources and conflict is often articulated only in one or two of the three possible ways. The first one is the 'resource curse' argument, as per which being dependent on resources weak- 
ens the economic growth as well as social and state institutions of a country, rendering it vulnerable to armed conflict. The second is the 'resource conflict' argument, based on which grievances, conflicts, and violence associated with the control and exploitation of natural resources increase the risk of largerscale armed conflicts. The third variant is the 'conflict resource' argument, which treats the opportunities that abundant and especially 'lootable' natural resources provide belligerents to finance their activities as a manifestation of the curse (Le Billon, 2001 and 2013: 13).

Each argument is, in turn, connected to a distinct characterisation of a given conflict. The resource curse argument points at the vulnerability to conflict of a given society, which accentuates as state institutions become weaker, less dependent on taxation and less supportive of social cohesion and regional integration. The resource conflict argument centres on the risk of conflict increasing on the basis of factors such as higher income inequality, grievances over socio-cultural-environmental externalities of the industry, and greater rewards for secession or state capture. The conflict resource argument, then, points at the opportunity for financing armed hostilities provided to belligerents through natural resources (ibid., 2013: 17). The triad framework resists the essentialising tendency of discussions on 'resource wars'. Taken alone, any of the three components fails to capture the complexity of the politically- and socially-mediated relationship between resources and conflicts. When adopted together for analytical purposes, the three components help explain how 'resource endowments, exploitation practices, social entitlements, and discursive representation' contribute to shaping the countries' vulnerability to, the risk of, and the opportunities for armed conflicts (ibid., 2013: 14 and 2001: 575).

\section{Due diligence schemes in Democratic Republic of the Congo}

\section{Aims}

A general consensus prevails that mineral wealth comprises one of the many factors shaping eastern DRC's dire situation (Le Billon, 2013; Humphreys, 2005; Ross, 2012; Stearns, 2014: 167). Since the early 2000s, the exploitation of ' $3 \mathrm{TG}$ ' minerals, that is, of tantalum, tungsten, tin and gold, has gained the 
most international attention. ${ }^{3}$ Armed groups control or regularly visit many mining sites: minerals constitute a useful source of revenue for a range of purposes, from paying salaries of fighters and boosting state budget to reinforcing criminal networks or local rebel rule (UN Group of Experts, 2010: 17; IPIS, 2015: 40; Stearns and Vogel, 2015). The term 'armed groups' is often a shorthand for various groups ranging from paramilitary organisations, village militias, and bandits to the Congolese army. Mineral revenues are important to all sides in the conflict: the Armed Forces of the Democratic Republic of the Congo (FARDC) are heavily involved with the mining business, and a major source of insecurity by itself (Parker and Vadheim, 2017: 8).

Accordingly, over the last decade, 'breaking the link between conflict and trade in natural resources' has become a visible part of the international efforts to assist the war-torn eastern DRC (Enough Project, 2009; Seay, 2012: 18). Two legislations serve a key role. In 2010, the United States Congress passed the Section 1502, or the Conflict Minerals Provision, of the DoddFrank Wall Street Reform and Consumer Protection Act. The Section 1502 obliges corporations registered with the Securities and Exchange Commission (SEC) to investigate and report the extent to which their supply chains sourcing from DRC and its neighbouring countries are 'conflict-free'. The legislation ignited a major revamp in the electronics industry, as companies operating in the United States were obliged to scrutinise their sourcing practices in order to avoid not only reputational damage but also legal repercussions. In 2017, the Section was suspended, although not abolished, by the Trump Administration (Supply Chain Dive, 2017). Crucially, the European Union has prepared similar legislation to ensure that 'conflict minerals' are not imported to Europe. The legislation, which comes to force in January 2021, is drafted on the blueprint of the Section 1502, but is global in scope where the Dodd-Frank Act focuses on the African Great Lakes region (Vlaskamp, 2019).

Different views prevail over what exactly the laws are to achieve. The grounding documents of the major conflict mineral frameworks indicate various purposes, ranging from 'conflict-free sourcing' and 'avoiding conflict contribution' to 'reducing human suffering' and 'promoting peace' (Diemel and

3. Congo is also a major source of cobalt. The mineral is not listed as a 'conflict mineral' in US and EU legislations, although allegations over child labour in mining it have attracted international scrutiny (Ndagano, 2020). 
Hilhorst, 2019). Public debate meshes together various aims, such as quenching regional black markets, safeguarding the US and EU interests in the area, preventing corporate reputational risk, and facilitating longer-term economic and social development (Whitney, 2015: 184; Vlaskamp, 2019; Prendergast, 2009: 3). An interviewee suggests that the subsequent debate on the efficacy of the schemes is 'cacophonic', involving academics, policy-makers, businesses and civil society in sometimes entrenched positions (Signatories of the letter 2014a; Signatories of the letter, 2014b; Enough Project, 2017; Geenen, $2017)^{4}$. Hence, one can argue that tackling conflict is wrong, or too much, to ask from the due diligence schemes. This article does not argue that supporting conflict prevention and resolution is the only aim of the schemes, but presumes that the schemes were and are advanced based on a rough empirical hypothesis: instability and violence recurring in eastern DRC can be alleviated by shaping the international demand of 3TG minerals. The section below takes up a for-against format to discuss the evidence accrued so far on their impact in the area.

\section{For}

Broadly, as per the supportive argument increasing the traceability of minerals has had or at least will advance peace and stability in eastern DRC.

First, armed groups have already become less present in 3TG mines since the Section 1502 was introduced in the United States. In 2017, the UN Group of Experts highlighted that despite severe challenges mineral traceability schemes have 'considerably reduced instances of armed groups directly benefiting from the exploitation and trade of tin, tantalum and tungsten' (UN Group of Experts, 2017: 2). Further, armed groups have fewer opportunities to indirectly benefit from the minerals, and it is now possible for international buyers to source minerals from eastern DRC that are free of armed group interference (ibid.: 18). Also quantitative analyses suggest that although armed groups continue to profit from mining indirectly, for instance by installing roadblocks, they are present in 3TG mines less often than prior to the DoddFrank Act (IPIS, 2015, 2019a and 2019b). Accordingly, calls have increased to strengthen due diligence efforts in the gold sector. The most established trace-

4. Interview \#19: Congo researcher working for an NGO. 
ability schemes do not cover this sector, even though around 80 percent of artisanal miners in eastern DRC work in gold mining sites and armed group presence remains strong (IPIS, 2015: 4; Sentry, 2018).

Second, the early problems of the schemes have been amended. Yannick Weyns, a natural resource expert at the UN peacekeeping operation MONUSCO, notes that some of the decrease in the price artisanal miners get, which is one of the suggested negative effects of the schemes, is due to an increased control and regulation of the sector in accordance with DRC's updated mining code rather than a direct consequence of the due diligence schemes ${ }^{5}$. Alternative traceability schemes, such as the Better Sourcing programme, are emerging to dismantle the monopsony status of the pioneering iTSCi mineral traceability initiative (Reuters, 2019). Civil society organisations are doing their best to ensure that 'accompanying measures', which take into account the impact of the legislation on livelihoods of local communities, are part of the forthcoming EU legislation (EURAC, 2017). Also on the corporate side, lessons in implementation have been learned (iTSCi, 2017a).

Third, it is still too early to judge the impact of the schemes on the area. Koch and Kinsbergen argue that it is unfortunate that the 'dominant narrative' of the de facto embargo hurting the population lingers on, although this early, 'intended' and maybe even necessary stage to 'flush out the rebels' is over. They predict that the negative consequences are likely to weaken in the middle and long term (Koch and Kinsbergen, 2018). The success of Section 1502 should be assessed in a time-frame of ten or twenty years rather than based on the very first years (Whitney, 2015: 184). The situation calls for persistence from international actors, and for subjecting the gold sector to similar treatment, instead of abandoning the schemes (IRIN News, 2017a, $2017 \mathrm{~b}$ and $2017 \mathrm{c}$ ). Hence, the ITA, an industry association, underlines that '[s] takeholders who lose sight of the general objective and expect total solutions to illegality and total elimination of risk will contribute to further harm to the situation in the DRC' (iTSCi, 2015).

Fourth, there are no viable alternatives in sight. To Salter and MthembuSalter, in the absence of a clear alternative policy framework, shaking the hardfought resolution to extend the due diligence schemes to gold and other minerals would be a mistake. Straw man arguments against the schemes abound,

5. Interview \#21: Yannick Weyns, Natural Resources Expert, MONUSCO, Goma. 
although policy-makers have not portrayed minerals as a root cause of the conflict rather than conceded that company due diligence can and should play a 'supporting role' in tackling the region's many problems. In the long run, industralisation is necessary to get eastern DRC off the ground, and this process will inevitably include land dispossession faced by local artisanal workers (Salter and Mthembu-Salter, 2016). A strategy could be developed to better compensate for their loss of livelihoods. From a developmental perspective, however, it is better to continue the due diligence efforts than to let armed groups profit from mineral funds as they did prior to 2011 (iTSCI, 2017a: 3). Hence, the traceability schemes and due diligence can reduce the potential for conflict in eastern $\mathrm{DRC}^{6}$.

\section{Against}

Broadly, as per the critical argument the due diligence schemes are either ineffective or harmful as it comes to advancing peace and stability in eastern DRC.

First, the immediate launch of the Dodd-Frank Act in 2010 was chaotic. Seay (2012: 16) argues that the law was conducive to creating a 'de facto ban' on Congolese mineral exports. The ban was further solidified by President Joseph Kabila's six-month ban on artisanal mining aimed at increasing pressure towards formalising the sector (see also Geenen, 2012: 326; Vogel and Raeymaekers, 2016: 1.111). Such regulation pushed major companies towards taking a 'Congo-free' instead of a 'conflict-free' approach to sourcing raw materials. A fall in demand of resources put anywhere from tens of thousands up to two million Congolese miners out of work in the eastern region, causing loss of livelihoods (Radley and Vogel, 2015: 407-409; Cuvelier et al., 2014). Furthermore, infant deaths increased in villages close to the mines that were 'treated' by the regulation. Such damage done to local livelihoods in the first years has been widely acknowledged (Parker and Vadheim, 2017; Parker et al., 2016; IPIS, 2019b; Enough Project, 2014; iTSCi, 2017a: 7).

Second, the schemes have achieved less than they are heralded for. Surely, the armed groups are now less present in especially $3 \mathrm{~T}$ mines than prior

6. Interview \# 17: Bali Barume and Martin Neumann, Project Manager \& Project Officer, BGR Bukavu; Interview \#9: Joel Omar, Senior Researcher, Justice for All, an NGO, Bukavu. 
to the Dodd-Frank, and armed violence in eastern DRC is currently not often related to interference in the artisanal mining sector (IPIS, 2019a: 8 ). The armed groups are fragmenting and clustering: around 120 groups operated in the two Kivu provinces alone in 2017, in contrast to 70 different groups in 2015 (Stearns and Vogel, 2017: 5). However, these changes do not mean that they are less active. Parker and Vadheim geographically locate the mines affected by the Dodd-Frank regulation to argue that the schemes broke down the 'stationary bandit' equilibrium, pushing armed groups to fight over gold-mining territories and to loot civilians beyond the vicinity of the 3T mines (Parker and Vadheim, 2017: 44). The armed groups' reduced presence in $3 \mathrm{~T}$ mines, which the due diligence schemes have indeed achieved, has not equalled to reduced violence and instability in eastern DRC (Bloem, 2018: 29-32).

Third, the schemes will remain hard or impossible to implement effectively in the unruly eastern DRC. Crucially, government troops do not have a monopoly of violence in the area. In a violence-prone environment, visiting mines for validation is time-consuming, difficult, costly, and sometimes dangerous. A mine validated as 'green' might nevertheless be controlled by an armed group soon after a visit (Radley and Vogel, 2015: $409)^{7}$. In 2014, the Group of Experts suggested that smuggling 3T minerals continues (UN Group of Experts 2014, 42). Three years later, the Group documented that iTSCi, 'while well intentioned and designed - has shortcomings in its implementation, enabling different actors to intentionally or inadvertently facilitate smuggling' (UN Group of Experts, 2017: 2). Breaches of the chain of custody and ongoing sale of bag tags on the black market in North Kivu persist. Low prices create an impetus for the artisanal miners to sell minerals to smugglers heading to Burundi, Uganda, Rwanda and other neighbouring countries, and encourage a shift to less regulated commodities, especially lucrative gold (UN Group of Experts, 2018: 2 and 2017: 6, 18 and 21; for an industry response: iTSCi, 2017b) ${ }^{8}$. Seay argues that implementing due diligence schemes in eastern DRC is vastly more challenging than establishing the Kimberley Process in Sierra Leone, where the state functions were more operational (Seay, 2012: 19). Generally, no

7. Interview \#17; see footnote nr. 6 .

8. Interview \#28: Seremi Chibashimba, President of Surveillance Commission, Former President of Cooperative, COMIKA, Kalehe. 
broad claims regarding the resource-conflict link can be made based on the unique Kimberley Process?

Fourth, it is unsure whether the schemes can weaken or disincentivise the armed groups. Especially earlier advocates of the schemes understated how the financial base of armed groups is never solely reliant on minerals. As Nest writes with regards to coltan, a mineral used to finance violence in the 2000s: '...following the price boom, coltan returned to being just one of many sources of income for armed groups, including, gold, tin, tungsten, manganese, timber, cattle, other livestock, wildlife, taxation of commerce, theft of consumer goods, theft of agricultural produce and control of international border posts' (Nest, 2011: 183). Recent reports echo that it is the commodification of not only minerals but of any resource, including people's labour and movement, which constitutes a key node in the conflict (Vogel and Raeymaekers, 2016: 1.114; IPIS and DIIS, 2017; IPIS, 2019a). After all, import regimes in Europe and North America have their limits: they can do little to obstruct the armed groups from financing themselves through the local or regional trade in goods.

\section{The resource curse perspective}

Based on above, what to make of the impact of the due diligence schemes besides that it is all very complicated? This article suggests that, on one hand, if the schemes are evaluated as tools of conflict prevention and resolution, there are well-grounded reasons to be concerned about their efficacy. The situation in eastern DRC has not improved over the past 10 years. On the other hand, important lessons on implementation and supportive measures have been learned on the way. The forthcoming EU legislation may help amend past shortcomings. Especially if critics do not present better means to address the role of minerals in eastern DRC's turmoil, calls to abolish the legal requirements to corporate due diligence sound hasty. Hence, preserving the momentum while calibrating the course is better than stopping the movement altogether.

The rest of the article argues for changing the course of the conflict mineral approach by strengthening the 'resource curse' perspective of Le Billon's triad framework. Some authors have recently articulated that the current approach

9. Interview \#59: Antonius de Vries, Former negotiator for the European Commission in the Kimberley Process. 
rests on 'strong assumptions' about the linkage between natural resources and combatant motivations (Parker and Vadheim, 2017: 45; Stoop et al., 2018a: 14-15). To nuance this analysis further, the due diligence schemes are predominantly built on the 'conflict resource' and 'resource conflict' perspectives of the situation in eastern DRC. As per these viewpoints, armed groups, whose motives and means to fight revolve around mineral wealth, are the main players in the conflict. Tackling their access to minerals best addresses the role of natural resources in eastern DRC's conflict. Broadly, the risk of an armed conflict is accentuated by the social processes linked with abundant minerals, and the opportunity for armed conflict emerges as groups of people can finance any violent activity of theirs through mineral wealth. The prevailing assumption is that due diligence may help curb both dimensions.

To compare, examining the so-

If the due diligence schemes are evaluated as tools of conflict prevention and resolution, there are well-grounded reasons to be concerned about their efficacy, since the situation in eastern DRC has not improved over the past 10 years. Although it is true that important lessons on implementation and supportive measures have been learned on the way. ciety's vulnerability to conflict puts other actors under the spotlight. To an extent, the 'resource curse' perspective resonates with recent conflict analyses emphasising the role of elite networks in the violence. Stearns and Vogel suggest that over the last years armed groups in eastern DRC have become more and more interwoven in the competition among the Congolese elite. Many armed groups retain almost symbiotic relations to military officers and politicians. They interact with the FARDC military officers to whom instability in eastern DRC provides a way to pursue their own interests. They also engage with politicians, who use the groups as a violent tool to build their own power bases and protection rackets. Local issues, including ethnic feuds, land use, and community tensions, prevail as the narrative through which armed groups justify their activities, and indeed some groups remain rooted to local grievances (Autessere, 2012). Yet, more and more of them are enmeshed in patronage and protection networks maintained by elites to whom the conflict has become an end itself (Stearns and Vogel, 2015; Vogel and Stearns, 2018).

The 'resource curse' perspective emphasises that such elite capture is made possible by the weakness of Congolese state institutions. DRC is not a 'failed' state; it serves as an apparatus inside which pipes of patronage used for private gain criss-cross (Vlassenroot and Raeymaekers, 2009; Lake, 2017). Accordingly, the Congolese government has little incentive to reforms such as those 
needed among the security forces in eastern DRC as long as the current webs of patronage support elite survival. There is not a functioning army, police or judicial system with means and a motive to establish a monopoly of violence in the peripheral east. For now, violence serves the regional, national and political elites, who compete over positions in which to tap on the opaque state-owned enterprises or to harness armed groups. Symmetrically, the population in eastern DRC has an impetus to sustain home militias and other armed groups to protect their lives, property and interests. The due diligence schemes are not designed to address such violent elite competition, a pivotal social context in which minerals become a conflict item.

Surely, this is nothing new. In the past, international donors have mistakenly presumed that Kinshasa has an incentive to enact a comprehensive security sector reform (Oxfam, 2012; Thill and Cimanuka, 2020). Salter and Mthembu-Salter remind that critics of the due diligence schemes easily resort to ambiguities 'in which the Congolese state appears to be presented both as the source of the deeper problems, and, paradoxically, as the solution' (Salter and Mthembu-Salter, 2016: 6). Yet, there is value in using the triad framework to help pinpoint the dimensions of the mineral-conflict link not addressed by the due diligence schemes. In the 2000s, civil society campaigners captured the popular imagination in Europe and the United States through the 'blood minerals' narrative. Neither this imagery nor the conflict mineral approach it helped establish have fully reflected the shifting, socially mediated role minerals play in the conflict. State weakness and natural resources prevail throughout DRC, but lead to armed mobilisation only when conjoined with social and political tensions. Such tensions exist between the elites to whom in the current situation violence appears as an effective competition strategy (Stearns, 2014: 158).

There is no panacea. However, building stronger connections to the fight against transnational money laundering and illicit capital flows is one possible way for the international donors to strengthen the 'resource curse' perspective in the current conflict mineral approach. This suggestion is broadly aligned with a handful of recent investigations on DRC's mineral wealth. Global Witness, a London-based investigative NGO, has drawn attention riches siphoned off at Gécamines, a state-owned company that dominates the Congolese largescale mining industry (Global Witness, 2017). A group of writers linked with the Enough Project, an American NGO, urges donor states and multinational companies to tackle the 'kleptocratic state' and 'grand corruption', suggesting that 'strategic pressure' has to be applied on the Congolese regime to support a change of trajectory in the country (Sentry, 2018; Callaway, 2018; Lezhnev 
and Prendergast, 2017; Prendergast, 2018). These calls do not target only Kinshasa. IPIS, a Belgian think tank, suggests that 'responsible sourcing efforts have not sufficiently recognised the dire need to improve governance' in eastern DRC (IPIS, 2019a: 54) ${ }^{10}$.

The international mechanisms enabling elite access to mineral wealth deserve international attention just as the access of armed groups does. Zoë Marriage points out that the illicit flow of capital from and to DRC is an 'elephant in the room', which sets the interests of foreign business and the political elite against those of the rest of the Congolese population (Marriage, 2018). The channels of capital flight can be an indirect explanans of the conflicts. Surely, international anti-corruption initiatives, such as the EITI and the NRGI, are already engaging in analysis and advocacy on natural resource governance (EITI, 2019). However, policy paths on natural resource management and conflict minerals have, interestingly, remained somewhat separate from each other. Marriage's work indicates transnational financial flows as a piece in the puzzle of dismantling the elite networks that instrumentalise the violence in eastern DRC for power and profit. Surely, addressing this cross-border aspect of the vulnerability to conflict is also a challenge to Le Billon's triad framework. However, the framework could be developed to better appreciate the transnational aspects of the conflict-resource link.

Putting into practice such a wider reading of the conflict minerals approach is inevitably easier said than done. In the United States, the Section 1504 of the Dodd-Frank Act, which is to tighten the transparency requirements for US companies in the oil, gas, forestry and mining sectors conducting payments to foreign governments, has met obstacles just as the Section 1502 on conflict minerals (Transparency International, 2020). As China's demand for commodities increases, establishing multilateral rules on corporate due diligence might become harder. And even if such steps could be taken, the fragmentation of armed groups, DRC's fractionalised security apparatus, and its weak state institutions constitute a long-term challenge that will take years to address (Vogel and Stearns, 2018: 707). Yet, potential remains in strengthening the linkages between the conflict mineral approach and various measures taken against transnational money laundering and illicit capital flows. Harnessing the triad framework helps capture why the latter kind of work is not

10. Interview \#27: Leopold Rutinigirwa Muliro and Adili Amani Romuald, Researcher and Researcher, Pole Institute, an NGO, Goma; Interview \#18: Remy Kasindi, Founder, CRESA, an NGO, Bukavu. 
separate from conflict prevention and resolution, but equals to addressing the 'resource curse' dimension of the mineral-conflict linkage.

\section{Conclusion}

Mandatory supply chain due diligence requirements to curb the international trade of 'conflict minerals' sourced from eastern DRC have been actively developed since 2010. This article has brought together recent reports and fieldwork findings to suggest that their impact on the violence and instability in the area remains ambiguous. Diverse expectations have been vested on them from the onset. Fewer 3TG mines are now controlled by armed militants than prior to the introduction of the mineral traceability efforts. However, the schemes have had negative consequences, such as the deterioration of local livelihoods and rising child mortality, and doubts prevail over their future impact. It is difficult to make a bal-

It might be possible to steer the momentum of the due diligence schemes to better address the vulnerability to conflict involved with DRC's mineral riches. One way to do so could be to strengthen the connections between the conflict mineral approach and the efforts to curb transnational money laundering and illicit capital flows from and to DRC. anced evaluation of whether the schemes can address minerals as a conflict item.

This article has suggested a triad framework to tease out some grounding assumptions of the conflict mineral approach as it now stands. The due diligence schemes, by assuming that minerals provide armed groups with means and a motive to conduct acts of violence, do not engage with all dimensions of the minerals as a conflict item. What is neglected is eastern DRC's vulnerability to conflict brought forth by minerals serving as an object of violent elite competition in a state apparatus hollowed out by their patronage networks. The competition among the political and military elite is expressed violently through armed groups. The triad framework serves as a reminder that minerals constitute a conflict item only when conjoined with such fluctuating social and political processes, in which the elite networks of patronage and protection currently have a pronounced role.

Sanctions regimes can persist at the same time as their purpose, context, and intent change (Eriksson, 2011). It might be possible to steer the momentum of the due diligence schemes to better address the vulnerability to conflict 
involved with DRC's mineral riches. One way to do so could be to strengthen the connections between the conflict mineral approach and the efforts to curb transnational money laundering and illicit capital flows from and to DRC. The latter kind of work has remained somewhat separate and largely in the shadow of the compelling 'blood mineral' imagery used to generate support for the due diligence schemes. Connecting these two areas to address the role of minerals in the conflict in eastern DRC requires conceptual rethinking in which Le Billon's triad framework may be of help.

\section{Bibliographical references}

Abbott, Kenneth and Duncan Snidal. "Strengthening international regulation through transnational new governance: Overcoming the orchestration deficit”. Vanderbildt Journal of Transnational Law, vol. 42, issue 1 (2009), pp. 501-577.

Acosta, Andrés Mejía. "The impact and effectiveness of accountability and transparency initiatives: the governance of natural resources". Development Policy Review, vol. 31, issue S1 (2013), pp. 89-105.

Aula, Ilari. Consuming conflicts: Consumer responsibility for armed conflicts in DR Congo and Nigeria. PhD Thesis (2019). London School of Economics and Political Science.

Autessere, Séverine. 'Dangerous Tales: Dominant Narratives on the Congo and Their Unintended Consequences'. African Affairs, vol. 111, issue 443 (2012), pp. 202-222.

Bieri, Franziska. From Blood Diamonds to the Kimberley Process: How NGOs Cleaned Up the Global Diamond Industry. Farnham Surrey: Ashgate, 2010.

Biersteker, Thomas, Sue E. Eckert, Marcos Tourinho (eds.) Targeted sanctions: The impacts and effectiveness of United Nations Action. New York, Cambridge University Press, 2016.

Biersteker, Thomas, Sue E. Eckert, Marcos Tourinho, Zuzana Hudáková (2013): Effectiveness of UN Targeted Sanctions. Targeted Sanctions Consortium.

Bloem, Jeffrey R. "Good Intentions Gone Bad? The Dodd-Frank Act and Conflict in Africa's Great Lakes Region". 2018 Annual Meeting, August 5-7, Washington, D.C, Agricultural and Applied Economics Association, 2018.

Callaway, Annie. "Powering Down Corruption". The Enough Project (2018) (online) [Accessed 21/05/2020] https://enoughproject.org/reports/power- 
ing-down-corruption

Carisch, Enrico; Loraine Rickard-Martin and Shawna Meister. 'Commodity Sanctions', in: Carisch, Rickard-Martin and Meister (eds.) The Evolution of UN Sanctions: From a Tool of Warfare to a Tool of Peace, Security and Human Rights. Springer, 2017.

Collier, Paul, and Anke Hoeffler. 'Greed and Grievance in Civil War' in $O x$ ford Economic Papers, vol. 56, issue 4 (2004), pp. 563-595.

Cuvelier, Jeroen; Steven Van Bockstael; Koen Vlassenroot and Claude Iguma. "Analyzing the Impact of the Dodd-Frank Act on Congolese Livelihoods" (2014). Social Science Research Council. (online) [Accessed 21/05/2020] https://www.ssrc.org/publications/view/analyzing-the-impact-of-thedodd-frank-act-on-congolese-livelihoods/

Diemel, J.A. and D.J.M. Hilhorst. "Unintended consequences or ambivalent policy objectives? Conflict minerals and mining reform in the Democratic Republic of Congo". Development Policy Review, vol. 37, issue 4 (2019), pp. 453-469.

Drezner, David. "Sanctions Sometimes Smart: Targeted Sanctions in Theory and Practice”. International Studies Review, vol. 13, issue 1 (2011), pp. 96-108.

EITI (2019): 2017 Democratic Republic of Congo EITI Report. EITI. (online) [Accessed 21/05/2020] https://eiti.org/files/documents/rapport_final_itie_congo_2017.pdf

Enough Project. "11 Letters from Congolese Civil Society Groups in Support of the U.S. Conflict Minerals Law" (2017) (online) [Accessed 21/05/2020] https://enoughproject.org/blog/seven-letters-congolese-groups-supportus-conflict-minerals-law

Enough Project. "Resource Page - Conflict Minerals: A Broader Push for Reform Is Essential" (2014) (online) [Accessed 21/05/2020] https://enoughproject.org/blog/resource-page-conflict-minerals-broader-push-reformessential

Enough Project. "A Comprehensive Approach to Congo's Conflict Minerals". Strategy Paper (2009) (online) [Accessed 21/05/2020] https://enoughproject.org/reports/comprehensive-approach-conflict-minerals-strategy-paper

Eriksson, Mikael "Targeting Peace: Understanding UN and EU targeted sanctions" (2011). Farnham/Abingdon, Ashgate.

EURAC. "Accompanying Measures to the EU Regulation on Responsible Mineral Sourcing". European Network for Central Africa (2017) (online) [Accessed 21/05/2020] https://www.eurac-network.org/sites/default/files/ position_paper_-_eng_accompanying_measures_to_the_eu_regulation_ on_responsible_mineral_sourcing_-_march_2017.pdf 
Geenen, Sara "A Dangerous Bet: The Challenges of Formalizing Artisanal Mining in the Democratic Republic of Congo". Resources Policy, vol. 37, issue 3 (2012), pp. 322-330.

Geenen, Sara. "Trump Is Right on Congo's Minerals, but for All the Wrong Reasons". The Conversation (22 February 2017) (online) [Accessed 21/05/2020] https://theconversation.com/trump-is-right-on-congos-minerals-but-for-all-the-wrong-reasons-73320

Gilberthorpe, Emma and Elissaios Papyrakis. "The Extractive Industries and Development: The Resource Curse at the Micro, Meso and Macro Levels". The Extractive Industries and Society, vol. 2, issue 2 (2015), pp. 381-390.

Giumelli, Francesco. Coercing, Constraining and Signalling: Explaining UN and EU Sanctions after the Cold War. Colchester: ECPR Press, 2011.

Global Witness. "Regime Cash Machine". Global Witness (2017) (online) [Accessed 21/05/2020] https://www.globalwitness.org/en/campaigns/democratic-republic-congo/regime-cash-machine/

Global Witness. "Global Witness leaves Kimberley Process, calls for diamond trade to be held accountable". Press release (2 December 2011) (online) [Accessed 21/05/2020] https://www.globalwitness.org/en/archive/global-witness-leaves-kimberley-process-calls-diamond-trade-be-held-accountable/

Global Witness. "Sinews of War: Eliminating the trade in conflict resources" (2006) (online) [Accessed 21/05/2020] https://cdn.globalwitness.org/archive/files/import/the_sinews_of_war.pdf

Haber, Stephen and Victor Menaldo. "Do Natural Resources Fuel Authoritarianism? A Reappraisal of the Resource Curse". American Political Science Review, vol. 105, issue 1 (2011), pp. 1-26.

Haufler, Virginia. "The Kimberley Process Certification Scheme: An Innovation in Global Governance and Conflict Prevention". Journal of Business Ethics, vol. 89, issue 4 (2009), pp. 403-416.

Humphreys, Macartan. "Natural Resources, Conflict, and Conflict Resolution Uncovering the Mechanisms". Journal of Conflict Resolution, vol. 49, issue 4 (2005), pp. 508-537.

IPIS-International Peace Information Service. "Mapping Artisanal Mining Areas and Mineral Supply Chains in Eastern DRC". Report. (2019a) (online) [Accessed 21/05/2020] https://ipisresearch.be/publication/mappingartisanal-mining-areas-mineral-supply-chains-eastern-drc/

IPIS-International Peace Information Service. "Assessing the Impact of Due Diligence Programmes in Eastern DRC: A Baseline Study". Report. (2019b) (online) [Accessed 21/05/2020] https://ipisresearch.be/publication/assessing-impact-due-diligence-programmes-eastern-drc-baseline-study/ 
IPIS-International Peace Information Service. "Analysis of the Interactive Map of Artisanal Mining in Eastern DRC”. 2015 Update. Report. (2015) (online) [Accessed 21/05/2020] https://ipisresearch.be/publication/analysis-interactive-map-artisanal-mining-areas-eastern-dr-congo-2/

IPIS-International Peace Information Service and DIIS-Danish Institute for International Studies "Everything That Moves Will Be Taxed": The Political Economy of Roadblocks in North and South Kivu". Report, (2017) (online) [Accessed 21/05/2020] https://ipisresearch.be/publication/everything-moves-will-taxed-political-economy-roadblocks-north-south-kivu/

IRIN News. "Who Pays the Hidden Price for Congo's Conflict-Free Minerals?". (14 February 2017a) (online) [Accessed 21/05/2020] https://www. thenewhumanitarian.org/investigations/2017/02/14/who-pays-hiddenprice-congo-s-conflict-free-minerals

IRIN News. "In Support of Dodd-Frank Conflict Minerals Regulation". (28 February 2017b)(online) [Accessed 21/05/2020] https://www.thenewhumanitarian.org/opinion/2017/02/28/support-dodd-frank-conflict-minerals-regulation

IRIN News "How Advocacy Gave Trump Ammunition on Conflict-Free Minerals". (6 April 2017c) (online) [Accessed 21/05/2020] https://www. thenewhumanitarian.org/investigations/2017/04/06/how-advocacy-gavetrump-ammunition-conflict-free-minerals

iTSCi. "ITSCi Views on Al Jazeera Fault Lines 'Conflicted: The Fight Over Congo's Minerals”. (2015) (online) [Accessed 21/05/2020] https://www. itsci.org/2015/11/14/itsci-views-al-jazeera-fault-lines-conflicted-fight-congos-minerals/

iTSCi. "Comments on January 31, 2017, Statement on the Commission's Conflict Minerals Rule”. (2017a) (online) [Accessed 21/05/2020] https:// www.sec.gov/comments/statement-013117/cll2-1646104-148416.pdf

iTSCi. "ITRI Comments on the UN Group of Experts Final Report". (2017b) (online) [Accessed 21/05/2020] https://www.itsci.org/2017/09/05/itricomments-un-group-experts-final-report/

Keen, David. "Greed and Grievance in Civil War". International Affairs, vol. 88, issue 4 (2012), pp. 757-777.

Koch, Dirk-Jan and Sara Kinsbergen. "Exaggerating Unintended Effects? Competing Narratives on the Impact of Conflict Minerals Regulation". Resources Policy, issue 57 (2018), pp. 255-263.

Lake, Milli. "Building the Rule of War: Postconflict Institutions and the Micro-Dynamics of Conflict in Eastern DRC", International Organization, vol. 71, issue 2 (2017), pp. 281-315. 
Le Billon, Philippe. Wars of Plunder: Conflicts, Profits and the Politics of Resources. New York, Oxford University Press, 2013.

Le Billon, Philippe. "Diamond Wars? Conflict Diamonds and Geographies of Resource Wars". Annals of the Association of American Geographers, vol. 98, issue 2 (2008), pp. 345-372.

Le Billon, Philippe. "Fatal Transactions: Conflict Diamonds and the (Anti) Terrorist Consumer". Antipode, vol. 38, issue 4 (2006), p. 778-801.

Le Billon, Philippe. "The political ecology of war: natural resources and armed conflict". Political Geography, vol. 20, issue 5 (2001), pp. 561-584.

Lezhnev, Sasha and John Prendergast. "Strategic Pressure". (2017) (online) [Accessed 21/05/2020] https://enoughproject.org/reports/strategic-pressure-blueprint-drc

Marriage, Zoë. "The Elephant in the Room: Offshore Companies, Liberalisation and Extension of Presidential Power in DRC". Third World Quarterly, vol. 39, issue 5 (2018), pp. 889-905.

Patricia Ndagano. "No, cobalt is not a conflict mineral. African Arguments". (5 May 2020) (online) [Accessed 21/05/2020] https://africanarguments. org/2020/05/05/no-cobalt-is-not-a-conflict-mineral/?fbclid=IwAR3_ Uz6UmObi0g8WibqZ5x_odUB42H3AspQaNSqa3aW1d9dIveOW2583S70

Nest, Michael. Coltan. Cambridge; Malden, MA: Polity, 2011.

Nillesen, Eleonora and Erwin Bulte. "Natural Resources and Violent Conflict". Annual Review of Resource Economics, vol. 6, issue 1 (2014), pp. 6983.

OECD. "Due Diligence Guidance for Responsible Supply Chains of Minerals from Conflict-Affected and High-Risk Areas". Paris. (2018) (online) [Accessed 21/05/2020] https://www.oecd.org/daf/inv/mne/mining.htm

Oxfam. "'For me, but without me, is against me': Why efforts to stabilize the eastern Congo are not working”. Oxfam Lobby Briefing. (2012) (online) [Accessed 21/05/2020] https://www.oxfamblogs.org/eastafrica/wp-content/uploads/2010/09/DRC-Stablisation-brief.pdf

Parker, Dominic P. and Bryan Vadheim. "Resource Cursed or Policy Cursed? US Regulation of Conflict Minerals and Violence in the Congo". Journal of the Association of Environmental and Resource Economists, vol. 4, issue 1 (2017), pp. 1-49.

Parker, Dominic P.; Jeremy D. Foltz and David Elsea. "Unintended Consequences of Economic Sanctions for Human Rights". Working Paper (2016). UNU-WIDER (online) [Accessed 21/05/2020] https://www.wider.unu. edu/publication/unintended-consequences-economic-sanctions-human- 
rights

Portela, Clara. European Union Sanctions and Foreign Policy. When and Why do they Work? London, Routledge, 2010.

Prendergast, John. "Briefing under the agenda item 'Maintenance of International Peace and Security' on corruption and conflict at the UN Security Council”. Enough Project (2018) (online) [Accessed 21/05/2020] https:// enoughproject.org/blog/john-prendergast-brief-historic-un-security-council-session-links-corruption-armed-conflict

Prendergast, John. "Can You Hear Congo Now? Cell Phones, Conflict Minerals, and the Worst Sexual Violence in the World". Enough Project. (2009) (online) [Accessed 21/05/2020] https://enoughproject.org/reports/canyou-hear-congo-now-cell-phones-conflict-minerals-and-worst-sexual-violence-world

Radley, Ben and Christoph Vogel. "Fighting Windmills in Eastern Congo? The Ambiguous Impact of the 'Conflict Minerals' Movement". The Extractive Industries and Society, vol. 2, issue 3 (2015), pp. 406-410.

Reuters. "Congo Miner SMB Leaves ITSCI Responsible-Sourcing Scheme over Cost”. (8 January 2019) (online) [Accessed 21/05/2020] https://www. reuters.com/article/us-itsci-congo/congo-miner-smb-leaves-itsci-responsible-sourcing-scheme-over-cost-idUSKCN1P20OV

Ross, Michael. The Oil Curse: How Petroleum Wealth Shapes the Development of Nations. Princeton; London: Princeton University Press, 2012.

Ross, Michael. "How Do Natural Resources Influence Civil War? Evidence from Thirteen Cases". International Organization, vol. 58, issue 1 (2004), pp. 35-67.

Sachs, Jeffrey D. and Andrew Warner. "Natural Resource Abundance and Economic Growth”. NBER Working Paper, issue 5398. (1995) (online) [Accessed 21/05/2020] https://www.nber.org/papers/w5398

Salter, Thomas and Gregory Mthembu-Salter. "A Response to Terr(It)or(Ies) of Peace? The Congolese Mining Frontier and the Fight against 'Conflict Minerals". Sulubu Working Papers, issue 2 (2016) (online) [Accessed 21/05/2020] https://ethuin.files.wordpress.com/2016/12/12122016-salter-suluhu-wp.pdf

Seay, Laura. "What's Wrong with Dodd-Frank 1502? Conflict Minerals, Civilian Livelihoods, and the Unintended Consequences of Western Advocacy". SSRN Scholarly Paper (2012). Rochester, NY: Social Science Research Network.

Sentry. "The Golden Laundromat. Enough Project \& Not on Our Watch" (2018) (online) [Accessed 21/05/2020] https://thesentry.org/reports/thegolden-laundromat/ 
Signatories of the letter. "An Open Letter" (2014a) (online) [Accessed 21/05/2020] https://ethuin.files.wordpress.com/2014/10/09092014open-letter-final-and-list-doc.pdf.

Signatories of the letter. "Open Letter: Broader Push for Reform Is Essential". (2014b) (online) [Accessed 21/05/2020] https://enoughproject.org/files/ OpenLetterConflictMinerals_October_2014.pdf.

Stearns, Jason and Christoph Vogel. "The Landscape of Armed Groups in the Eastern Congo: Fragmented, politicized networks". Congo Research Group, New York University (2015). (online) [Accessed 21/05/2020] http://congoresearchgroup.org/wp-content/uploads/2015/11/The-Landscape-of-Armed-Groups-in-Eastern-Congo 1.pdf.

Stearns, Jason. "Causality and Conflict: Tracing the Origins of Armed Groups in the Eastern Congo". Peacebuilding, vol. 2, issue 2 (2014), pp. 151-171.

Stearns, Jason, Judith Verweijen, and Maria Eriksson Baaz. "The National Army and Armed Groups in the Eastern Congo: Untangling the Gordian Knot of Insecurity". Rift Valley Institute. (2013) (online) [Accessed 21/05/2020] http://riftvalley.net/publication/national-army-and-armedgroups-eastern-congo

Stearns, Jason. Dancing in the Glory of Monsters. New York, PublicAffairs, 2011.

Stoop, Nik; Marijke Verpoorten, and Peter van der Windt. "More Legislation, More Violence? The Impact of Dodd-Frank in the DRC". PLOS ONE, vol. 13 , issue 8 (2018a).

Stoop, Nik; Marijke Verpoorten, and Peter van der Windt. "Trump Threatened to Suspend the 'Conflict Minerals' Provision of Dodd-Frank. That Might Actually Be Good for Congo". Washington Post. (27 September 2018b) (online) [Accessed 21/05/2020] https://www.washingtonpost. $\mathrm{com} /$ news/monkey-cage/wp/2018/09/27/trump-canceled-the-conflictminerals-provision-of-dodd-frank-thats-probably-good-for-the-congo/

Supply Chain Dive. "SEC Suspends Conflict Mineral Rule Enforcement" (11 April 2017) (online) [Accessed 21/05/2020] https://www.supplychaindive. com/news/SEC-conflict-mineral-rule-dodd-frank-enforcement/440175/.

Thill and Cimanuka. "Governing local security in the eastern Congo: Decentralization, police reform and interventions in the chieftaincy of Bukavu". Rift Valley Institute. (2020) (online) [Accessed 21/05/2020] https://riftvalley.net/sites/default/files/publication-documents/Governing\%20local\%20 security $\% 20$ in $\% 20$ the $\% 20$ eastern $\% 20$ Congo $\% 20$ by $\% 20$ Michel $\% 20$ Thill\%20 and \% 20Abel\%20 Cimanuka \% 20-\%20RVI\%20 and \% 20 VNGi\%20report\%20\%282020\%29.pdf 
Transparency International. "Proposed U.S. rule ill-equipped to prevent secret payments by oil, gas, forestry \& mining companies". Press Release. (16 March 2020) (online) [Accessed 21/05/2020] https://www.transparency. $\mathrm{org} / \mathrm{en} / \mathrm{press} /$ proposed-u-s-rule-ill-equipped-to-prevent-secret-paymentsby-oil-gas-forestry-mining-companies

UN. Guiding Principles on Business and Human Rights: Implementing the United Nations "Protect, Respect and Remedy" Framework. New York, Geneva, 2011. (online) [Accessed 21/05/2020] https://www.unglobalcompact.org/ library/2

UN Group of Experts. "Interim Report of the Group of Experts on the Democratic Republic of the Congo". (25 May 2010) (online) [Accessed 21/05/2020] https://www.undocs.org/S/2010/252

UN Group of Experts. "Final Report of the Group of Experts on the Democratic Republic of the Congo". (23 January 2014) (online) [Accessed 21/05/2020] https://www.undocs.org/S/2014/42

UN Group of Experts. "Final Report of the Group of Experts on the Democratic Republic of the Congo". (10 August 2017) (online) [Accessed 21/05/2020] https://www.undocs.org/S/2017/672/Rev.1

UN Group of Experts. "Midterm Report of the Group of Experts on the Democratic Republic of the Congo". (18 December 2018) (online) [Accessed 21/05/2020] https://www.undocs.org/S/2018/1133

Vlaskamp, Martijn C.. "The European Union and natural resources that fund armed conflicts: Explaining the EU's policy choice for supply chain duediligence requirements". Cooperation and conflict, vol. 54, issue 3 (2019), p. 407-425.

Vlassenroot, Koen and Timothy Raeymaekers. "Kivu's Intractable Security Conundrum". African Affairs, vol. 108, issue 432 (2009), pp. 475-484.

Vogel, Christoph and Jason Stearns. "Kivu's Intractable Security Conundrum, Revisited". African Affairs, vol. 117, issue 469 (2018), pp. 695-707.

Vogel, Christoph and Timothy Raeymaekers. "Terr(It)or(Ies) of Peace? The Congolese Mining Frontier and the Fight Against 'Conflict Minerals'”. Antipode, vol. 48, issue 4 (2016), pp. 1102-1121.

Weiss, T. "Sanctions as a Foreign Policy Tool: Weighing Humanitarian Impulses". Journal of Peace Research, vol. 36, issue 5 (1999), pp. 499-509.

Whitney, Toby. "Conflict Minerals, Black Markets, and Transparency: The Legislative Background of Dodd-Frank Section 1502 and Its Historical Lessons". Journal of Human Rights, vol. 14, issue 2 (2015), pp. 183-200. 


